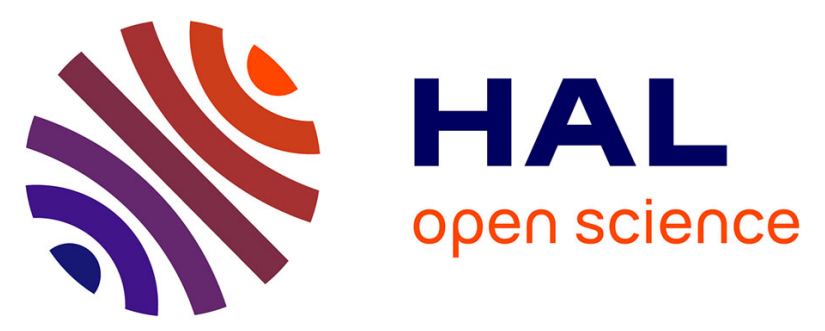

\title{
The pipeline of targeted therapies under clinical development for primary Sjögren's syndrome: A systematic review of trials
}

Renaud Felten, Florence Scher, Jean Sibilia, Jacques-Eric Gottenberg, Laurent Arnaud

\section{To cite this version:}

Renaud Felten, Florence Scher, Jean Sibilia, Jacques-Eric Gottenberg, Laurent Arnaud. The pipeline of targeted therapies under clinical development for primary Sjögren's syndrome: A systematic review of trials. Autoimmunity Reviews, 2019, 18, pp.576 - 582. 10.1016/j.autrev.2018.12.008 . hal03484634

\section{HAL Id: hal-03484634 \\ https://hal.science/hal-03484634}

Submitted on 20 Dec 2021

HAL is a multi-disciplinary open access archive for the deposit and dissemination of scientific research documents, whether they are published or not. The documents may come from teaching and research institutions in France or abroad, or from public or private research centers.
L'archive ouverte pluridisciplinaire HAL, est destinée au dépôt et à la diffusion de documents scientifiques de niveau recherche, publiés ou non, émanant des établissements d'enseignement et de recherche français ou étrangers, des laboratoires publics ou privés.

\section{다)(1) $(5$}

Distributed under a Creative Commons Attribution - NonCommerciall 4.0 International 


\section{The 2018 pipeline of targeted therapies under clinical development for primary Sjögren's syndrome: a systematic review of trials}

\section{Renaud FELTEN ${ }^{1,2,3}$, Florence SCHER ${ }^{4}$, Jean SIBILIA ${ }^{1,3,5}$, Jacques-Eric GOTTENBERG ${ }^{1,2,3}$, Laurent ARNAUD1, 3, 5}

1 Service de rhumatologie, Hôpitaux Universitaires de Strasbourg, F-67000 Strasbourg, France.

${ }^{2}$ Laboratoire d'Immunologie, Immunopathologie et Chimie Thérapeutique, Institut de Biologie Moléculaire et Cellulaire (IBMC), CNRS UPR3572

${ }^{3}$ RESO : Centre de Référence des Maladies Autoimmunes Systémiques Rares Est Sud-Ouest

${ }^{4}$ Service de Pharmacie-Stérilisation, Hôpitaux Universitaires de Strasbourg

5 Service de rhumatologie, Hôpitaux Universitaires de Strasbourg, Laboratoire d'ImmunoRhumatologie Moléculaire, INSERM UMR_S1109, Université de Strasbourg, F-67000 Strasbourg, France.

\section{Corresponding author:}

Pr. Laurent ARNAUD, Service de rhumatologie, Centre National de Référence des Maladies Autoimmunes et Systémiques Rares, Hôpital de Hautepierre, 1 Avenue Molière BP 83049, 67098 Strasbourg Cedex, France. Phone: 0388128474 |Fax: 03 88128290 | email: Laurent.arnaud@ chru-strasbourg.fr 


\section{ABSTRACT}

To date, no immunomodulatory drug has proved efficacious in primary Sjögren's syndrome (pSS). In pSS, difficulties in drug efficacy assessment is related to the large spectrum of clinical involvements (glandular/extraglandular involvement), to the lack of correlation between symptoms of dryness and glandular function assessed by objective measurements, as well as between symptoms and systemic complications of the disease. Severe organ manifestations are generally treated by off-label therapies in accordance with current practice and guidelines for Systemic Lupus Erythematosus or other connective-tissue diseases. Despite a much greater understanding of the pathogenesis of pSS, modern drug development has resulted in no approval of therapy so far. In this study, we performed a systematic review of all targeted therapies under clinical development in pSS, in 17 main online registries of clinical trials. Our search identified 264 trials, from which 25 targeted therapies for pSS were included. The molecules under current clinical development for pSS target B cells $(n=4), T$ cells or $T / B$ cells costimulation $(n=5)$, inflammatory cytokines or chemokines and their receptors $(n=5)$, intracellular signalling pathways $(n=7)$ and various other targets identified in pSS $(n=4)$. The current drug development pipeline in pSS may lead to valuable strategies for the treatment of this currently difficultto-treat disease.

\section{Keywords}

Sjögren's syndrome; Therapeutics; treatments; Targeted therapies; Clinical Trials; Immunosuppressive Agents 


\section{Introduction}

Primary Sjögren's syndrome (pSS) is a complex systemic autoimmune disease characterized by a wide spectrum of clinical and laboratory findings and variable course and outcomes. On the basis of formal criteria for the diagnosis [1], which require the presence of immunologic abnormalities (the presence of serum antiSSA antibodies or focal lymphocytic sialadenitis on biopsy of labial salivary glands), the estimated prevalence is 0.3 to 1 per 1000 persons with a female-tomale predominance of 9:1 and a peak incidence at approximately 50 years of age [2]. The pathogenesis of pSS is not fully elucidated (Figure 1), but the disease has been recognized as the result of a complex interplay between immunological, genetic and environmental factors implying both innate and adaptative immunity. Despite autoimmune conditions are principally due to $\mathrm{T}$ and $\mathrm{B}$ lymphocytes, NK cells also appear to play a role in the promotion and/or maintenance of altered adaptive immune responses or in peripheral tolerance mechanisms [3]. pSS follows a typical multistep model of human autoimmune diseases characterized by loss of immunologic tolerance to self-antigens, permissive production of autoantibodies, and subsequent emergence of clinical symptoms [4,5]. To date, no immunomodulatory drug has proved efficacious in pSS. Severe organ manifestations are generally treated in accordance with current practice and guidelines for SLE or other connective-tissue diseases. Thus, several unmet needs remain for the treatment of pSS, and the medical community is avid for treatments. New research has improved our understanding of disease mechanisms, with notable advances in our knowledge about the genetic susceptibility of disease [6], the complex role of interferon pathways [7] and the molecular process of the chronic autoimmune response in exocrine glands [8]. The pipeline of drugs under development for the treatment of pSS is enriched with novel biologics and small molecular entities targeting these pathogenic processes such as in Systemic Lupus Erythematosus (SLE) $[9,10]$. The purpose of this systematic review is to provide the reader with an updated view of targeted therapies currently under clinical development in pSS. 


\section{Methods}

We performed a systematic review of all targeted therapies under clinical development in pSS, in the main online registries of clinical trials. Targeted therapies were defined as drugs specifically designed to block certain molecules, receptors, or pathways involved in the development of autoimmune diseases. Clinical development stages were defined as phases I, II \& III. Were excluded from this systematic review all pharmacological agents leading to a non-specific blockade of the immune system, such as classical immunosuppressive agents. Two authors (R.F. \& F.S.) searched 17 national and international databases of clinical trials (Table 1) using the keywords "Sjögren's syndrome", "Sjögren" and "Sjogren" (date of search: the 13 ${ }^{\text {th }}$ of May 2018). Expert feedback was used to identify additional trials. Duplicates were excluded and each study was subsequently classified in consensus as whether it involved or not a targeted therapy for pSS, based on the descriptions provided in the registries or additional evidence gathered through the main internet search engines. Finally, targeted therapies for pSS were classified according to their mechanisms of action, and the current stage of drug development was extracted from the registries. 


\section{Results}

Our search identified 264 trials, from which 25 targeted therapies for pSS were included in this review. The study selection process and reasons for exclusion are shown in Figure 2. For each therapy, we considered only the study at the most advanced stage of clinical development.

The candidate drugs reached phase I ( $n=2), I / I I(n=1)$, Phase II $(n=19)$, phase II/III $(n=2)$ and phase III $(n=1)$. The 23 corresponding trials were completed $(n=8)$, recruiting $(n=6)$, terminated $(n=4)$, active but not recruiting $(n=4)$ and withdrawn $(\mathrm{n}=1)$.

Molecules under current clinical development for pSS target B cells $(n=4)$, T cells or $\mathrm{T} / \mathrm{B}$ cells costimulation $(\mathrm{n}=5)$, inflammatory cytokines or chemokines and their receptors $(n=5)$, intracellular signalling pathways $(n=7)$ and various other targets identified in pSS $(n=4)$ (Figure 1$)$.

\section{B cell therapies}

B cells can be selectively targeted either via direct B cell molecules such as CD20 or by inhibition of B cell survival factors such as B lymphocyte stimulator (BLyS/BAFF).

Four molecules target B cells (Figure 3 and Table 2), assessed in 5 trials: phase II ( $n=4,2$ recruiting, 1 completed and 1 terminated) or phase II/III (n=1 completed).

The use of rituximab, a chimeric anti-CD20 antibody, in patients with pSS has been investigated in four completed randomised controlled trials [11-14] showing no significant improvement in a composite primary end-point or for fatigue or oral dryness in the larger studies $[13,14]$. However, most experts agree that rituximab may be useful for the treatment of some systemic manifestations of pSS, especially cryoglobulinemia-induced vasculitis $[15,16]$.

An open-label phase II study suggested the efficacy of belimumab, an inhibitor of BAFF, in $60 \%$ of patients, as assessed by an improvement in at least two of five disease indicators, including dryness, pain, fatigue, systemic activity, and B-cell biomarkers [17]. However, there was no significant improvement in salivary flow or tear production as assessed by Schirmer's test. 
After rituximab treatments, serum BAFF levels increased when B cells were depleted from the circulation in pSS patients. When B cells reappeared, BAFF levels declined [18]. Given the role of BAFF in pSS, combination of anti-BAFF treatment with rituximab may lead to a prolonged reduction of (autoreactive) B cells. Sequential therapy with belimumab followed by rituximab or their coadministration may also be effective for pSS-related B-cell lymphoproliferation [19]. The safety and the efficacy of subcutaneous belimumab and intravenous rituximab co-administration are currently under evaluation in a phase II (recruiting) study.

Another treatment targeting BAFF is under evaluation: VAY736 an anti-BAFFReceptor (recruiting phase II). Of note, tibulizumab, an anti-BAFF and anti-IL17A bispecific antibody is also being evaluated (phase I, active, not recruiting, cf. Other mechanisms of action).

Baminercept a Lymphotoxin-Beta receptor fusion protein has been tested in a phase II study, which is terminated. Despite an ESSDAI improvement significantly higher in the baminercept group than with placebo, baminercept therapy was no more effective than placebo for increasing salivary flow or reducing ocular dryness, and was accompanied by an imbalance in transaminase elevations and 2 cases of reversible grade 3 hepatic injury [20].

\section{Inhibition of T cells or B/T Cell Co-Stimulation}

Two distinct signals are necessary for the activation of $\mathrm{T}$ cells. The first signal involves the binding of antigen to the T-cell receptor. The second signal occurs with the interaction between receptor-ligand pairs on the $\mathrm{T}$ cells and antigen presenting cells that include the B cells.

Five molecules targeting $\mathrm{T}$ cells or the $\mathrm{B} / \mathrm{T}$ cell co-stimulation have been evaluated in pSS (Figure 3 and Table 2): in phase II ( $n=4,2$ terminated, 1 active, but not recruiting and 1 recruiting) or phase III ( $n=1$, active but not recruiting). The interaction of CD80 or CD86 molecule on B cells and CD28 on T cells provides an important second co-stimulatory signal for T-cell activation, which is important for the subsequent production of antibodies by the B cells. A fusion protein consisting of CTLA4 and an immunoglobulin chain (CTLA4-Ig or abatacept) binds CD80 or CD86 with a higher affinity than CD28 and inhibits this 
co-stimulatory pathway. Abatacept is being assessed in pSS in a phase III study (active but not recruiting) after two phase II open-label trials [21,22].

Another receptor-ligand pair, CD40 (on B cells) and CD40L or CD154 (on T cells), also provides an important co-stimulatory signal for T- and B-cell activation. CFZ533, an anti-CD40 antibody is currently being tested in a recruiting phase II trial with preliminary results presented at the 2017 ACR congress [23].

ICOS and its ligand (ICOSL) have been shown to play diverse roles in T-cell responses such as mediating autoimmunity as well as enhancing the development/activity of regulatory $\mathrm{T}$ cells (Tregs). Prezalumab, an anti-ICOS antibody and AMG 557, an anti-B7RP-1 (ICOSL) antibody is being evaluated in phase II (active but not recruiting).

Lulizumab pegol is an anti-CD28 monoclonal antibody. CD28 is the co-receptor for the $\mathrm{T}$ cell receptor. Lulizumab pegol has been assessed in a phase II trial which was prematurely terminated.

Efalizumab is a recombinant humanized monoclonal antibody which binds to CD11a. Efalizumab has been evaluated in autoimmune diseases, including pSS, but was associated with fatal brain infections and was withdrawn from the market in 2009.

\section{Targeting cytokines and their receptors}

Five treatments targeting inflammatory cytokines/chemokines or their receptors have been tested in pSS (Figure 4 and Table 3$)$, in phase II $(n=4,3$ completed, 1 withdrawn) or phase II/III ( $n=1$, active but not recruiting).

TNF- $\alpha$ is a pleiotropic pro-inflammatory cytokine. The overexpression of TNF $\alpha$ has been detected in glandular lesions both in animal models of primary SS and in humans [24,25]. A randomized phase II controlled trials of infliximab [26] (which has not been identified by our registry search) and etanercept [27] showed no significant improvement in a composite primary outcome on a visualanalogue scale of joint pain, fatigue, and dryness.

Anakinra, an anti-IL1RA antibody, has been tested in a phase II trial in which did not reach its primary endpoint [28].

IL- 6 is mainly secreted by activated macrophages and $\mathrm{T}$ cells and is induced by 
other cytokines such as TNF and IFN. Serum IL-6 is increased in serum, saliva, and tears of patients with pSS $[29,30]$. IL-6 plays a pivotal role in B-cell activation, a hallmark of the pathogenesis of pSS, as well as in T-cell differentiation. Tocilizumab, a recombinant humanised anti-IL-6R monoclonal antibody is being tested in a phase II/III placebo-controlled study (active but not recruiting).

Treatment with low-dose IL-2 selectively enhances Tregs functions [31] while avoiding the activation of effector $\mathrm{T}$ cells and may therefore improve immune inflammation. Administration of low doses of IL-2 to pSS patients has been tested in a completed phase II trial (pending results).

GSK2618960 is a humanized Immunoglobulin G1 monoclonal antibody that binds to the alpha component (CD127) of the heterodimeric Interleukin-7 receptor (IL-7R). The molecule has been evaluated in a phase II study (stopped for portfolio prioritization).

Tibulizumab is an anti-BAFF and anti-IL17A bispecific antibody, being evaluated in an active phase I study (cf. Other mechanisms of action).

\section{Small molecules targeting intracellular signalling pathways}

Seven small molecules targeting intracellular signalling pathways are in the pSS pipeline (Figure 4 and Table 3), in five trials of phase II $(n=4,2$ terminated and 1 completed, 1 recruiting) or phase I/II ( $\mathrm{n}=1$, recruiting).

$\mathrm{PI} 3 \mathrm{k} \delta$ is a signaling molecule crucial for BAFF receptor 3 function [32], two studies are now underway in pSS to investigate the potential benefits of a small molecule selective PI $3 \mathrm{k} \delta$ inhibitor: Leniolisib (completed phase II, pending results) and seletalisib [33](terminated phase II, study stopped prematurely due to enrolment challenges).

Because type I interferons signal through JAKs to induce IFN-stimulated gene expression [34], therapeutic inhibitors of JAKs have appeared as potentially valuable drugs in pSS. Filgotinib an highly selective JAK1 inhibitor [35] is being evaluated in a recruiting phase II trial. In the same trial, two others arms are evaluating GS-9876, a Spleen tyrosine kinase (Syk) inhibitor and tirabrutinib a Bruton's Tyrosine Kinase inhibitor (BTKi). Syk is involved in the regulation of the TLR7/9 pathway in human pDCs [36]. BTK is a cytoplasmic, non-receptor 
tyrosine kinase that transmits signals from a variety of cell-surface molecules, including the B-cell receptor (BCR) [37]. Another BTKi, BMS-986142, a, has been tested in a phase II study which was prematurely terminated because of an inability to meet protocol objectives and the withdrawnal of lulizumab tested in an other arm of the same trial.

Iguratimod, a small molecule used as a novel disease-modifying antirheumatic drug for treatment of rheumatoid arthritis in Japan and China displayed significantly inhibition of immunoglobulin production and suppression of IL-1, IL-6 and TNF [38] through NFkB pathway [39]. Iguratimod is being assessed in a currently recruiting phase I/II trial.

\section{Other mechanisms of action}

Four molecules with other mechanisms of action are in the pSS pipeline (Table 3): two in phase II (1 completed, 1 recruiting) and two in phase I ( 1 completed, 1 active, not recruiting).

Tibulizumab, an anti-BAFF and anti-IL17A bispecific antibody is being evaluated in an active phase I study. The expression of IL-17 is increased in patients with pSS and IL-17 level correlates with the disease severity of pSS [40].

MEDI7734 an anti-ILT7 antibody targets plasmacytoïd dendritic cells (pDCs) and has been tested in a completed phase I. pDCs produce type I interferon (IFN) after Toll-like receptor (TLR) activation. Human pDCs preferentially express immunoglobulin-like transcript 7 (ILT7), which couples with a signaling adapter to activate a prominent immunoreceptor tyrosine-based activation motif (ITAM)-mediated signaling pathway [41].

RSLV-132, a fully human biologic Fc fusion protein of human RNase and Fc domain of human IgG1, is assessed in a recruiting phase II study. The drug is designed to remain in circulation and digest extracellular RNA with the aim of preventing activation of the immune system via Toll-like receptors and the interferon pathway [42].

Inhibition of cathepsin-S in vivo alters autoantigen presentation and development of organ-specific autoimmunity [43]. R05459072, a cathepsin-S inhibitor [44] has been evaluated in a completed phase II trial (pending results). 


\section{Conclusion}

Primary Sjögren's syndrome (pSS) definitely lacks any specific immunosupressive treatment. In pSS, the mainstay of therapeutic options is delivered mostly by off-label therapies. Modern drug development has resulted in no approval of therapy so far. One could speculate whether some previous controlled trials revealed negative in pSS because of the inefficacy of the evaluated drug or because of the adopted clinical trial design. Therefore, the proper definition of optimal outcome measures is crucial to set up new clinical trials in pSS. The currently ongoing trials all included only patients with systemic complications and based the definition of their primary outcome criteria on the change in the internationally validated ESSDAI score [45]. Along with improvements in the understanding of the pathogenesis of pSS, this allows to be reasonably optimistic on the future development of effective targeted therapies in pSS. 


\section{REFERENCES}

[1] Shiboski CH, Shiboski SC, Seror R, Criswell LA, Labetoulle M, Lietman TM, et al. 2016 American College of Rheumatology/European League Against Rheumatism classification criteria for primary Sjögren's syndrome: A consensus and data-driven methodology involving three international patient cohorts. Ann Rheum Dis 2017;76:9-16. doi:10.1136/annrheumdis2016-210571.

[2] Qin B, Wang J, Yang Z, Yang M, Ma N, Huang F, et al. Epidemiology of primary Sjögren's syndrome: a systematic review and meta-analysis. Ann Rheum Dis 2015;74:1983-9. doi:10.1136/annrheumdis-2014-205375.

[3] NK cells in autoimmune diseases: Linking innate and adaptive immune responses. Autoimmun Rev 2018;17:142-54. doi:10.1016/j.autrev.2017.11.018.

[4] Brennan MT, Sankar V, Leakan RA, Grisius MM, Collins MT, Fox PC, et al. Sex steroid hormones in primary Sjögren's syndrome. J Rheumatol 2003;30:1267-71.

[5] Kivity S, Arango MT, Ehrenfeld M, Tehori O, Shoenfeld Y, Anaya J-M, et al. Infection and autoimmunity in Sjogren's syndrome: a clinical study and comprehensive review. J Autoimmun 2014;51:17-22. doi:10.1016/j.jaut.2014.02.008.

[6] Lessard CJ, Li H, Adrianto I, Ice JA, Rasmussen A, Grundahl KM, et al. Variants at multiple loci implicated in both innate and adaptive immune responses are associated with Sjögren's syndrome. Nat Genet 2013;45:1284-92. doi:10.1038/ng.2792.

[7] Yao Y, Liu Z, Jallal B, Shen N, Rönnblom L. Type I interferons in Sjögren's syndrome. Autoimmun Rev 2013;12:558-66. doi:10.1016/j.autrev.2012.10.006.

[8] Navarro-Mendoza EP, Aguirre-Valencia D, Posso-Osorio I, Correa-Forero SV, Torres-Cutiva D-F, Loaiza D, et al. Cytokine markers of B lymphocytes in minor salivary gland infiltrates in Sjögren's syndrome. Autoimmun Rev 2018. doi:10.1016/j.autrev.2018.02.003.

[9] Chasset F, Arnaud L. Targeting interferons and their pathways in systemic lupus erythematosus. Autoimmun Rev 2018;17:44-52. doi:10.1016/j.autrev.2017.11.009.

[10] Felten R, Dervovic E, Chasset F, Gottenberg J-E, Sibilia J, Scher F, et al. The 2018 pipeline of targeted therapies under clinical development for Systemic Lupus Erythematosus: a systematic review of trials. Autoimmun Rev 2018.

[11] Dass S, Bowman SJ, Vital EM, Ikeda K, Pease CT, Hamburger J, et al. Reduction of fatigue in Sjögren syndrome with rituximab: results of a randomised, double-blind, placebo-controlled pilot study. Ann Rheum Dis 2008;67:1541-4. doi:10.1136/ard.2007.083865.

[12] Meijer JM, Meiners PM, Vissink A, Spijkervet FKL, Abdulahad W, Kamminga $\mathrm{N}$, et al. Effectiveness of rituximab treatment in primary Sjögren's syndrome: a randomized, double-blind, placebo-controlled trial. Arthritis Rheum 2010;62:960-8. doi:10.1002/art.27314.

[13] Devauchelle-Pensec V, Mariette X, Jousse-Joulin S, Berthelot J-M, Perdriger A, Puéchal X, et al. Treatment of primary Sjögren syndrome with rituximab: 
a randomized trial. Ann Intern Med 2014;160:233-42. doi:10.7326/M131085.

[14] Bowman SJ, Everett CC, O’Dwyer JL, Emery P, Pitzalis C, Ng W-F, et al. Randomized Controlled Trial of Rituximab and Cost-Effectiveness Analysis in Treating Fatigue and Oral Dryness in Primary Sjögren's Syndrome. Arthritis Rheumatol Hoboken NJ 2017;69:1440-50. doi:10.1002/art.40093.

[15] Gottenberg J-E, Cinquetti G, Larroche C, Combe B, Hachulla E, Meyer O, et al. Efficacy of rituximab in systemic manifestations of primary Sjogren's syndrome: results in 78 patients of the AutoImmune and Rituximab registry. Ann Rheum Dis 2013;72:1026-31. doi:10.1136/annrheumdis2012-202293.

[16] Giacomelli R, Afeltra A, Alunno A, Baldini C, Bartoloni-Bocci E, Berardicurti 0 , et al. International consensus: What else can we do to improve diagnosis and therapeutic strategies in patients affected by autoimmune rheumatic diseases (rheumatoid arthritis, spondyloarthritides, systemic sclerosis, systemic lupus erythematosus, antiphospholipid syndrome and Sjogren's syndrome)?: The unmet needs and the clinical grey zone in autoimmune disease management. Autoimmun Rev 2017;16:911-24. doi:10.1016/j.autrev.2017.07.012.

[17] Mariette X, Seror R, Quartuccio L, Baron G, Salvin S, Fabris M, et al. Efficacy and safety of belimumab in primary Sjogren's syndrome: results of the BELISS open-label phase II study. Ann Rheum Dis 2013. doi:10.1136/annrheumdis-2013-203991.

[18] Pollard RPE, Abdulahad WH, Vissink A, Hamza N, Burgerhof JGM, Meijer JM, et al. Serum levels of BAFF, but not APRIL, are increased after rituximab treatment in patients with primary Sjogren's syndrome: data from a placebo-controlled clinical trial. Ann Rheum Dis 2013;72:146-8. doi:10.1136/annrheumdis-2012-202071.

[19] De Vita S, Quartuccio L, Salvin S, Picco L, Scott CA, Rupolo M, et al. Sequential therapy with belimumab followed by rituximab in Sjögren's syndrome associated with B-cell lymphoproliferation and overexpression of BAFF: evidence for long-term efficacy. Clin Exp Rheumatol 2014;32:490-4.

[20] St.Clair E, Baer A, Noaiseh G, Parke A, Coca A, Utset T, et al. The Clinical Efficacy and Safety of Baminercept, a Lymphotoxin-Beta Receptor Fusion Protein, in Primary Sjögren's Syndrome: Results from a Randomized, Double-Blind, Placebo-Controlled Phase II Trial. ACR Meet Abstr n.d. http://acrabstracts.org/abstract/the-clinical-efficacy-and-safety-ofbaminercept-a-lymphotoxin-beta-receptor-fusion-protein-in-primarysjogrens-syndrome-results-from-a-randomized-double-blind-placebocontrolled-phase-ii-trial/ (accessed May 21, 2018).

[21] Meiners PM, Vissink A, Kroese FGM, Spijkervet FKL, Smitt-Kamminga NS, Abdulahad WH, et al. Abatacept treatment reduces disease activity in early primary Sjögren's syndrome (open-label proof of concept ASAP study). Ann Rheum Dis 2014;73:1393-6. doi:10.1136/annrheumdis-2013-204653.

[22] Tsuboi H, Matsumoto I, Hagiwara S, Hirota T, Takahashi H, Ebe H, et al. Efficacy and safety of abatacept for patients with Sjögren's syndrome associated with rheumatoid arthritis: rheumatoid arthritis with orencia trial toward Sjögren's syndrome Endocrinopathy (ROSE) trial-an open-label, 
one-year, prospective study-Interim analysis of 32 patients for 24 weeks. Mod Rheumatol 2015;25:187-93. doi:10.3109/14397595.2014.951144.

[23] Fischer B, et al. The Novel Anti-CD40 Monoclonal Antibody CFZ533 Shows Beneficial Effects in Patients with Primary Sjögren's Syndrome: A Phase IIa Double-Blind, Placebo-Controlled Randomized Trial. ACR Meet Abstr n.d. https://acrabstracts.org/abstract/the-novel-anti-cd40-monoclonalantibody-cfz533-shows-beneficial-effects-in-patients-with-primarysjogrens-syndrome-a-phase-iia-double-blind-placebo-controlledrandomized-trial/ (accessed June 22, 2018).

[24] Fox RI, Kang HI, Ando D, Abrams J, Pisa E. Cytokine mRNA expression in salivary gland biopsies of Sjögren's syndrome. J Immunol Baltim Md 1950 1994;152:5532-9.

[25] Koski H, Janin A, Humphreys-Beher MG, Sorsa T, Malmström M, Konttinen YT. Tumor necrosis factor-alpha and receptors for it in labial salivary glands in Sjögren's syndrome. Clin Exp Rheumatol 2001;19:131-7.

[26] Mariette X, Ravaud P, Steinfeld S, Baron G, Goetz J, Hachulla E, et al. Inefficacy of infliximab in primary Sjögren's syndrome: results of the randomized, controlled Trial of Remicade in Primary Sjögren's Syndrome (TRIPSS). Arthritis Rheum 2004;50:1270-6. doi:10.1002/art.20146.

[27] Sankar V, Brennan MT, Kok MR, Leakan RA, Smith JA, Manny J, et al. Etanercept in Sjögren's syndrome: a twelve-week randomized, doubleblind, placebo-controlled pilot clinical trial. Arthritis Rheum 2004;50:22405. doi:10.1002/art.20299.

[28] Norheim KB, Harboe E, Gøransson LG, Omdal R. Interleukin-1 inhibition and fatigue in primary Sjögren's syndrome--a double blind, randomised clinical trial. PloS One 2012;7:e30123. doi:10.1371/journal.pone.0030123.

[29] Grisius MM, Bermudez DK, Fox PC. Salivary and serum interleukin 6 in primary Sjögren's syndrome. J Rheumatol 1997;24:1089-91.

[30] Tishler M, Yaron I, Geyer 0, Shirazi I, Naftaliev E, Yaron M. Elevated tear interleukin-6 levels in patients with Sjögren syndrome. Ophthalmology 1998;105:2327-9. doi:10.1016/S0161-6420(98)91236-2.

[31] Yu A, Zhu L, Altman NH, Malek TR. A low interleukin-2 receptor signaling threshold supports the development and homeostasis of T regulatory cells. Immunity 2009;30:204-17. doi:10.1016/j.immuni.2008.11.014.

[32] Nayar S, Campos J, Buckley C, Allen R, Fahy W, Payne A. Phosphatidylinositol-3-Kinase Delta Pathway a Novel Therapeutic Target for Sjogren's Syndrome. ACR Meet Abstr n.d. http://acrabstracts.org/abstract/phosphatidylinositol-3-kinase-deltapathway-a-novel-therapeutic-target-for-sjogrens-syndrome/ (accessed May 22, 2018).

[33] Helmer E, Watling M, Jones E, Tytgat D, Jones M, Allen R, et al. First-inhuman studies of seletalisib, an orally bioavailable small-molecule PI3K $\delta$ inhibitor for the treatment of immune and inflammatory diseases. Eur J Clin Pharmacol 2017;73:581-91. doi:10.1007/s00228-017-2205-7.

[34] Horvath CM. The Jak-STAT pathway stimulated by interferon alpha or interferon beta. Sci STKE Signal Transduct Knowl Environ 2004;2004:tr10. doi:10.1126/stke.2602004tr10.

[35] Namour F, Diderichsen PM, Cox E, Vayssière B, Van der Aa A, Tasset C, et al. Pharmacokinetics and Pharmacokinetic/Pharmacodynamic Modeling of 
Filgotinib (GLPG0634), a Selective JAK1 Inhibitor, in Support of Phase IIB Dose Selection. Clin Pharmacokinet 2015;54:859-74. doi:10.1007/s40262015-0240-z.

[36] Aouar B, Kovarova D, Letard S, Font-Haro A, Florentin J, Weber J, et al. Dual Role of the Tyrosine Kinase Syk in Regulation of Toll-Like Receptor Signaling in Plasmacytoid Dendritic Cells. PLoS ONE 2016;11. doi:10.1371/journal.pone.0156063.

[37] Vargas L, Hamasy A, Nore BF, Smith CIE. Inhibitors of BTK and ITK: State of the New Drugs for Cancer, Autoimmunity and Inflammatory Diseases. Scand J Immunol n.d.;78:130-9. doi:10.1111/sji.12069.

[38] Bloom J, Metz C, Nalawade S, Casabar J, Cheng KF, He M, et al. Identification of Iguratimod as an Inhibitor of Macrophage Migration Inhibitory Factor (MIF) with Steroid-sparing Potential. J Biol Chem 2016;291:26502-14. doi:10.1074/jbc.M116.743328.

[39] Li G, Yamasaki R, Fang M, Masaki K, Ochi H, Matsushita T, et al. Novel disease-modifying anti-rheumatic drug iguratimod suppresses chronic experimental autoimmune encephalomyelitis by down-regulating activation of macrophages/microglia through an NF- $\kappa$ B pathway. Sci Rep 2018;8:1933. doi:10.1038/s41598-018-20390-5.

[40] Zhang L-W, Zhou P-R, Wei P, Cong X, Wu L-L, Hua H. Expression of interleukin-17 in primary Sjögren's syndrome and the correlation with disease severity: A systematic review and meta-analysis. Scand J Immunol 2018;87:e12649. doi:10.1111/sji.12649.

[41] Cao W, Bover L. Signaling and ligand interaction of ILT7: receptor-mediated regulatory mechanisms for plasmacytoid dendritic cells. Immunol Rev 2010;234:163-76. doi:10.1111/j.0105-2896.2009.00867.x.

[42] Burge DJ, Eisenman J, Byrnes-Blake K, Smolak P, Lau K, Cohen SB, et al. Safety, pharmacokinetics, and pharmacodynamics of RSLV-132, an RNaseFc fusion protein in systemic lupus erythematosus: a randomized, doubleblind, placebo-controlled study. Lupus 2017;26:825-34. doi:10.1177/0961203316678675.

[43] Saegusa K, Ishimaru N, Yanagi K, Arakaki R, Ogawa K, Saito I, et al. Cathepsin $\mathrm{S}$ inhibitor prevents autoantigen presentation and autoimmunity. J Clin Invest 2002;110:361-9. doi:10.1172/JCI14682.

[44] Theron M, Bentley D, Nagel S, Manchester M, Gerg M, Schindler T, et al. Pharmacodynamic Monitoring of R05459072, a Small Molecule Inhibitor of Cathepsin S. Front Immunol 2017;8. doi:10.3389/fimmu.2017.00806.

[45] Seror R, Ravaud P, Bowman SJ, Baron G, Tzioufas A, Theander E, et al. EULAR Sjogren's syndrome disease activity index: development of a consensus systemic disease activity index for primary Sjogren's syndrome. Ann Rheum Dis 2010;69:1103-9. doi:10.1136/ard.2009.110619. 
Figure 1. The complex pathogenesis of pSS and targets of pSS treatments

1. Targeting B cells

2. Targeting $\mathrm{T}$ cells or $\mathrm{B} / \mathrm{T}$ cells co-stimulation

3. Targeting cyto/chemokines and their receptors

4. Small molecules targeting intracellular signalling pathways

5. Other mechanisms of action

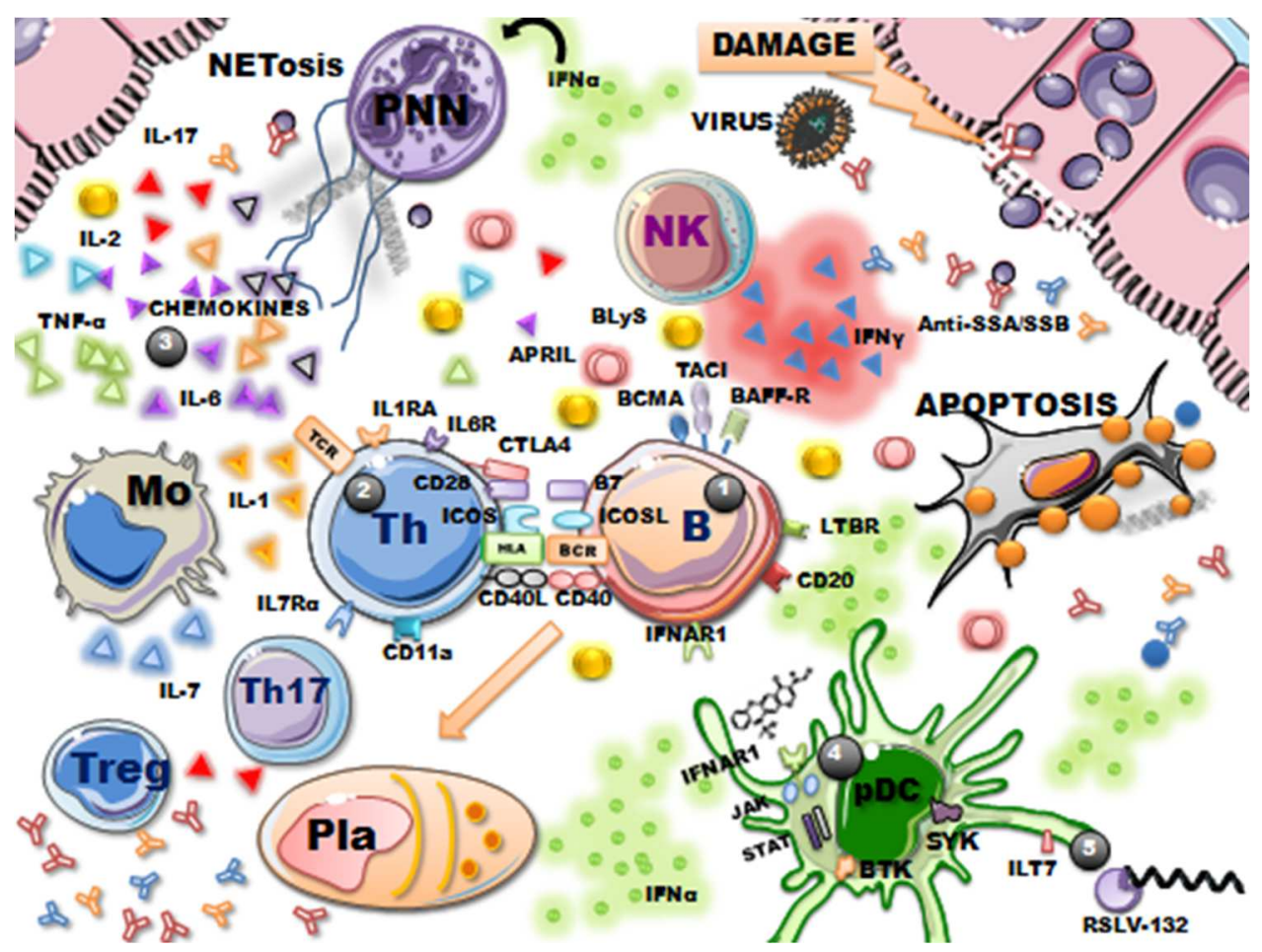




\section{Figure 2. Flow-chart of study selection}

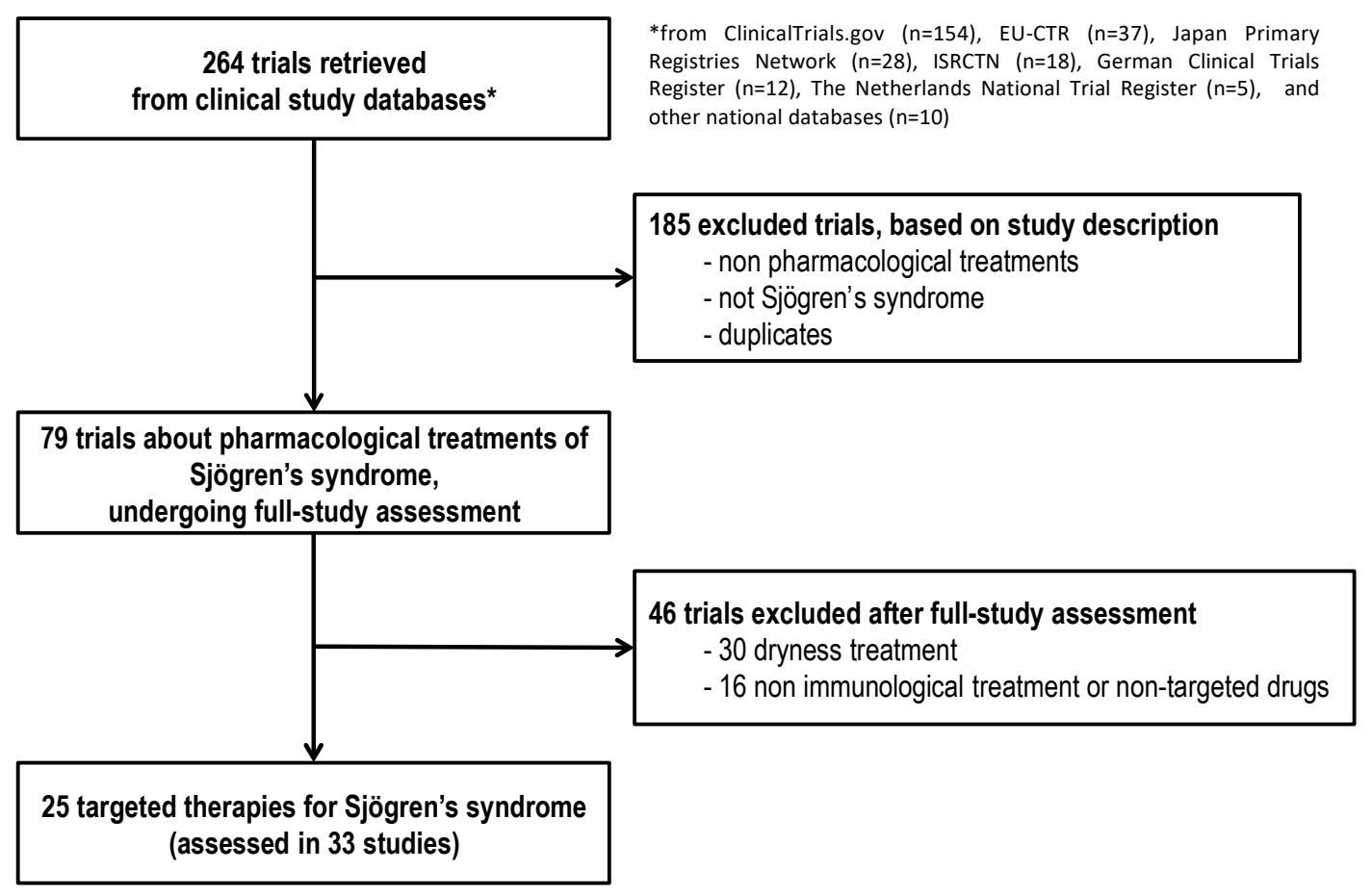


Figure 3. B cells, $\mathrm{T}$ cells and $\mathrm{B} / \mathrm{T}$ cells co-stimulation targeting therapies
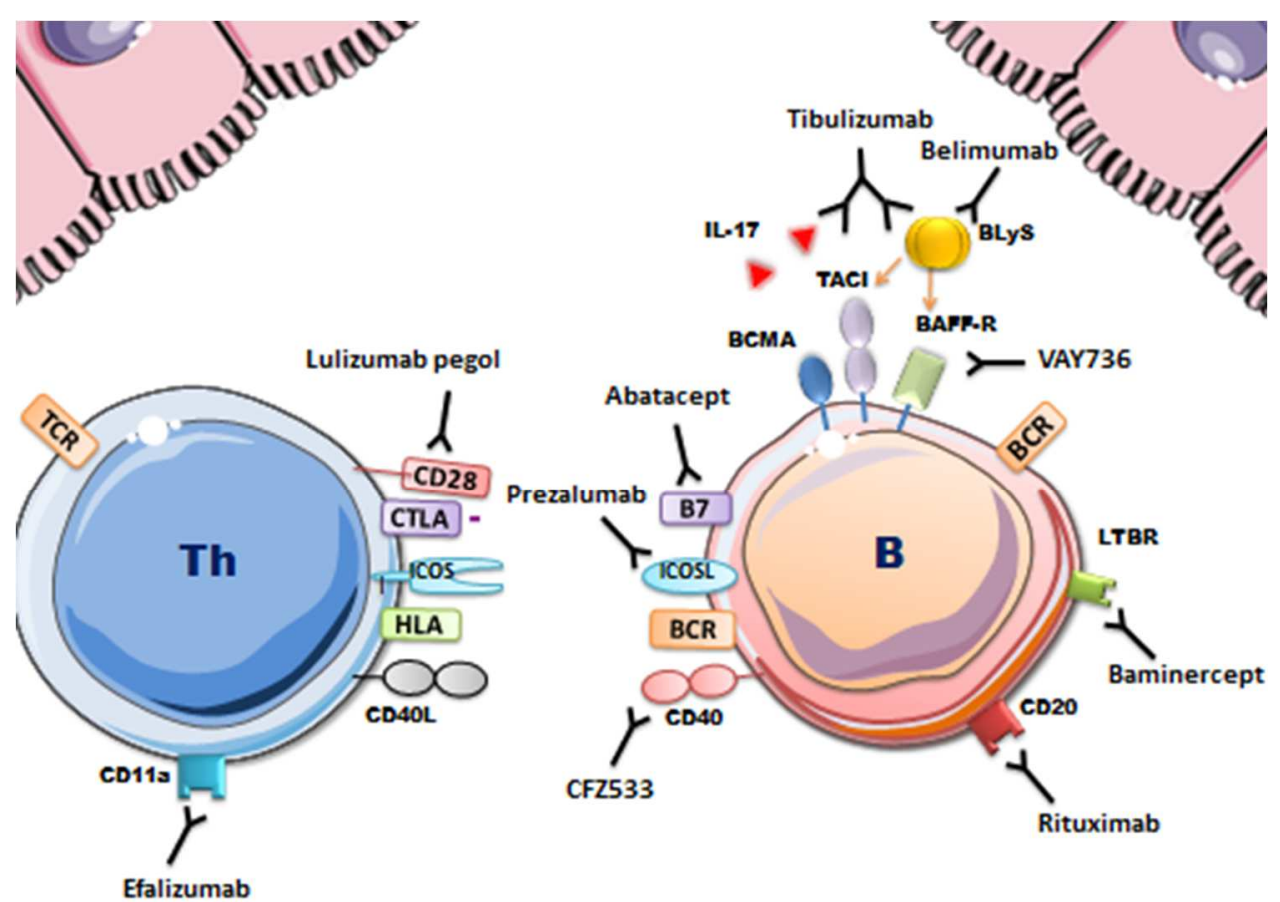
Figure 4. Cytokines and chemokines (or their receptors) targeting therapies and small molecules targeting intracellular signalling pathways

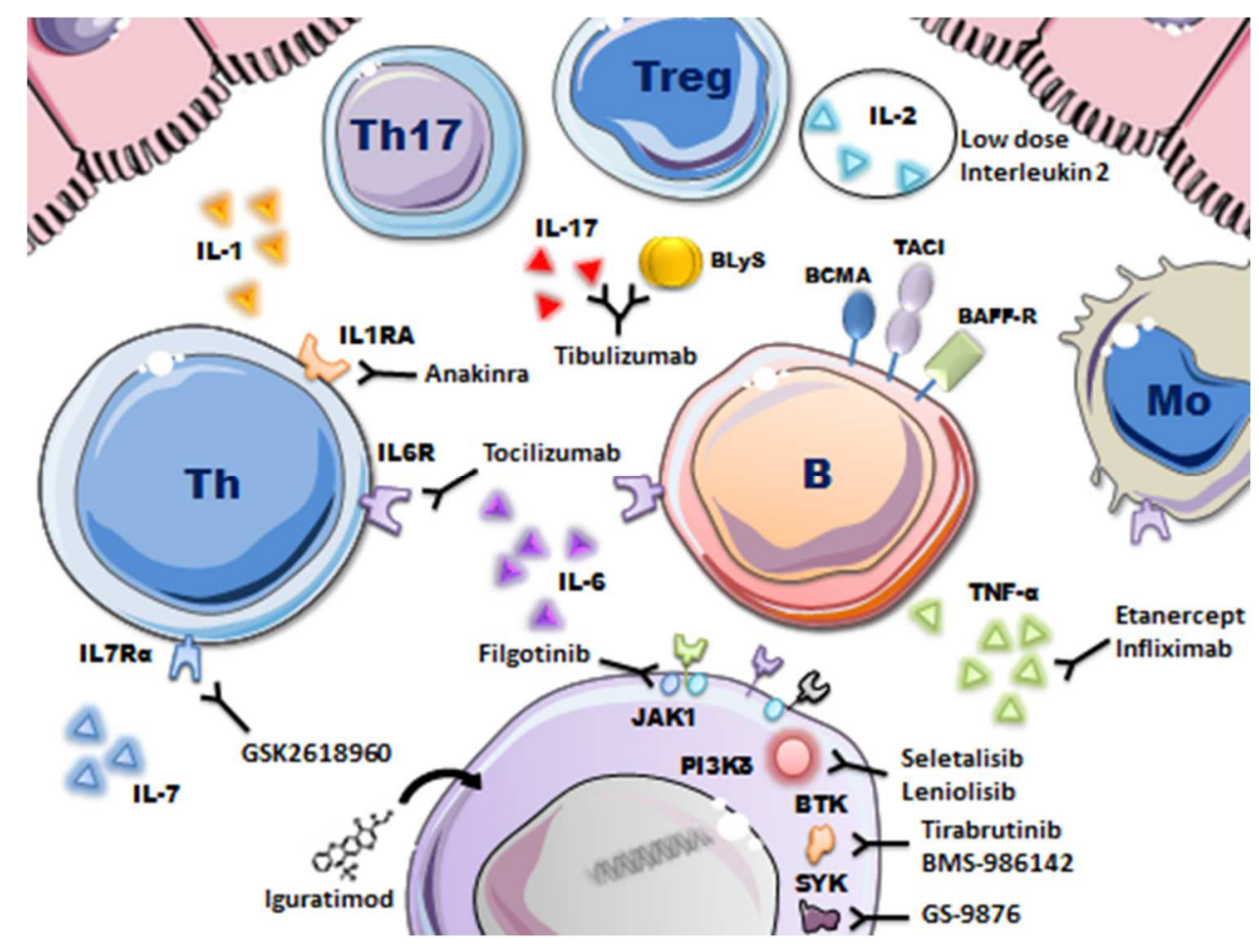


Table 1. List of international and national databases of clinical trials used for this systematic review

\begin{tabular}{|c|c|c|}
\hline Name of the database & $\begin{array}{l}\text { Number of pSS } \\
\text { trials indentified }\end{array}$ & Website URL \\
\hline ClinicalTrials.gov & 154 & https://clinicaltrials.gov \\
\hline $\begin{array}{l}\text { EU Clinical Trials Register } \\
\text { (EU-CTR) }\end{array}$ & 37 & $\begin{array}{l}\text { https://www.clinicaltrialsreg } \\
\underline{\text { ister.eu }}\end{array}$ \\
\hline $\begin{array}{l}\text { Japan Primary Registries } \\
\text { Network }\end{array}$ & 28 & http://www.umin.ac.jp/ctr/ \\
\hline $\begin{array}{l}\text { ISRCTN (International } \\
\text { Standard Randomised } \\
\text { Controlled Trial Number) }\end{array}$ & 18 & https://www.isrctn.com \\
\hline $\begin{array}{l}\text { German Clinical Trials } \\
\text { Register }\end{array}$ & 12 & https://www.drks.de \\
\hline $\begin{array}{l}\text { The Netherlands National } \\
\text { Trial Register }\end{array}$ & 5 & http://www.trialregister.nl \\
\hline $\begin{array}{l}\text { Australian New Zealand } \\
\text { Clinical Trials Registry }\end{array}$ & 2 & $\begin{array}{l}\text { https://www.australianclinic } \\
\text { altrials.gov.au }\end{array}$ \\
\hline $\begin{array}{l}\text { Chinese Clinical Trial } \\
\text { Registry }\end{array}$ & 2 & http://www.chictr.org.cn \\
\hline $\begin{array}{l}\text { Cuban Public Registry of } \\
\text { Clinical Trials }\end{array}$ & 2 & http://registroclinico.sld.cu \\
\hline $\begin{array}{l}\text { Brazilian Clinical Trials } \\
\text { Registry (ReBec) }\end{array}$ & 1 & $\begin{array}{l}\text { http://www.ensaiosclinicos.g } \\
\text { ov.br }\end{array}$ \\
\hline $\begin{array}{l}\text { Clinical Research } \\
\text { Information Service - } \\
\text { Republic of Korea }\end{array}$ & 1 & https://cris.nih.go.kr \\
\hline $\begin{array}{l}\text { Clinical Trials Registry - } \\
\text { India }\end{array}$ & 1 & http://ctri.nic.in \\
\hline $\begin{array}{l}\text { Iranian Registry of Clinical } \\
\text { Trials }\end{array}$ & 1 & www.irct.ir \\
\hline $\begin{array}{l}\text { Pan african Clinical Trial } \\
\text { Registry }\end{array}$ & 0 & http://www.pactr.org \\
\hline $\begin{array}{l}\text { Peruvian Clinical Trials } \\
\text { Registry }\end{array}$ & 0 & $\begin{array}{l}\text { http://www.ensayosclinicos- } \\
\text { repec.ins.gob.pe }\end{array}$ \\
\hline $\begin{array}{l}\text { Sri Lanka Clinical Trials } \\
\text { Registry }\end{array}$ & 0 & $\underline{\text { http://slctr.lk }}$ \\
\hline Thai Clinical Trials Register & 0 & $\underline{\text { http://www.clinicaltrials.in.t }}$ \\
\hline
\end{tabular}


Table 2. Molecules targeting B cells, $\mathrm{T}$ cells or B/T cell co-stimulation

\begin{tabular}{|l|l|l|l|}
\hline \multicolumn{1}{|c|}{ Molecules } & \multicolumn{1}{|c|}{$\begin{array}{c}\text { Mechanisms of } \\
\text { action }\end{array}$} & \multicolumn{1}{|c|}{$\begin{array}{c}\text { Current } \\
\text { development } \\
\text { Phase }\end{array}$} & \multicolumn{1}{c|}{$\begin{array}{c}\text { Current } \\
\text { development } \\
\text { Stage }\end{array}$} \\
\hline \multicolumn{4}{|c|}{ cells } \\
\hline Rituximab & anti-CD20 & Phase 2|Phase 3 & Completed \\
\hline Belimumab & anti-BAFF & Phase 2 & Completed \\
\hline Belimumab/Rituximab & anti-BAFF/anti-CD20 & Phase 2 & Recruiting \\
\hline VAY736 & anti-BAFF-R & Phase 2 & Recruiting \\
\hline Baminercept & $\begin{array}{l}\text { Lymphotoxin-Beta } \\
\text { Receptor Fusion } \\
\text { Protein }\end{array}$ & Phase 2 & Terminated \\
\hline \multicolumn{1}{|c|}{ T cells or B/T cell co-stimulation } & \\
\hline Abatacept & CTLA-Ig & Phase 3 & $\begin{array}{l}\text { Active, not } \\
\text { recruiting }\end{array}$ \\
\hline CFZ533 & anti-CD40 & Phase 2 & Recruiting \\
\hline Lulizumab pegol & anti-CD28 & Phase 2 & Terminated \\
\hline Prezalumab & anti-B7RP-1 (ICOSL) & Phase 2 & $\begin{array}{l}\text { Active, not } \\
\text { recruiting }\end{array}$ \\
\hline Efalizumab & anti-CD11a & Phase 2 & Terminated \\
\hline
\end{tabular}


Table 3. Molecules targeting cytokines, chemokines or their receptors, small molecules targeting intracellular signalling pathways and molecules with other mechanisms of action

\begin{tabular}{|c|c|c|c|}
\hline Molecules & Mechanisms of action & $\begin{array}{c}\text { Current } \\
\text { development } \\
\text { Phase } \\
\end{array}$ & $\begin{array}{c}\text { Current } \\
\text { development } \\
\text { Stage } \\
\end{array}$ \\
\hline \multicolumn{4}{|c|}{ Cytokines, chemokines or their receptors } \\
\hline Etanercept & anti-TNF & Phase 2 & Completed \\
\hline Tocilizumab & anti-IL-6R & Phase 2|Phase 3 & $\begin{array}{l}\text { Active, not } \\
\text { recruiting }\end{array}$ \\
\hline hrIL-2 & Low dose of IL-2 & Phase 2 & Completed \\
\hline Anakinra & anti-IL-1RA & Phase 2 & Completed \\
\hline GSK2618960 & anti-IL-7R $\alpha$ & Phase 2 & Withdrawn \\
\hline \multicolumn{4}{|c|}{ Small molecules targeting intracellular signalling pathways } \\
\hline Filgotinib & selective JAK1 inhibitor & \multirow{3}{*}{ Phase 2} & \multirow{3}{*}{ Recruiting } \\
\hline GS-9876 & Syk inhibitor & & \\
\hline Tirabrutinib & BTK inhibitor & & \\
\hline BMS-986142 & BTK inhibitor & Phase 2 & Terminated \\
\hline Seletalisib & $\begin{array}{l}\text { selective PI3K } \delta \\
\text { inhibitor }\end{array}$ & Phase 2 & Terminated \\
\hline Leniolisib & $\begin{array}{l}\text { selective PI3K } \delta \\
\text { inhibitor }\end{array}$ & Phase 2 & Completed \\
\hline Iguratimod & $\begin{array}{l}\text { suppression of nuclear } \\
\text { factor kappa B (NF-kB) } \\
\text { activation }\end{array}$ & Phase 1|Phase 2 & Recruiting \\
\hline \multicolumn{4}{|c|}{ Other mechanisms of action } \\
\hline Tibulizumab & $\begin{array}{l}\text { anti-BAFF and anti- } \\
\text { IL17A }\end{array}$ & Phase 1 & $\begin{array}{l}\text { Active, not } \\
\text { recruiting }\end{array}$ \\
\hline MEDI7734 & anti-ILT7 (pDCs) & Phase 1 & Completed \\
\hline RSLV-132 & RNase-Fc fusion protein & Phase 2 & Recruiting \\
\hline R05459072 & Cathepsine-S inhibitor & Phase 2 & Completed \\
\hline
\end{tabular}

